\title{
The Relation of Eruption of Third Molar Teeth and the Development of Individual in Jaipur Population
}

\author{
Anil Goyal
}

Assisstant Professor, Department of Pedodontics, Government Dental College, Jaipur, Rajasthan, India.

\begin{abstract}
Forensic science deals with age estimation and identification of individual in medicolegal purpose. Identification of person by two methods one is complete and another is partial method. The hard tissues are able to resist to decay and degradation in the human dentition. This knowledge is utilized by dentist's is relatively a new science is known as "Forensic Odontology". Socioeconomic status, religion physical characters such as built, secondary sexual characters (pubic hair, axillary hair, facial hair \& breast development) and teeth are also helpful for development and estimation of age of the individuals. The present study shows the relation of the development of individual and eruption of third molar teeth in various age groups in both sexes by radiograph in Jaipur population.
\end{abstract}

\section{INTRODUCTION}

Forensic science is a subtle discipline for estimation of age and it should be an important part of every identification process, especially when information which is related to the deceased is unavailable. The hard tissues of the human dentition are able to resist decay and degradation, long after other tissues are lost. This resistance has made teeth useful indicators for assessing variations in diet, expression of metabolic diseases, and calculation of age at the time of death ${ }^{1}$.The age determination of individual is necessary for the law enforcement agencies in field of medicolegal professions ${ }^{2}$.

There are three periods in human life, each differing in relation to tooth development. The first period is from utero to the time of eruption of the first tooth. The second phase is from age of eruption of the first tooth to about 12 years, the third follows when almost all permanent teeth are already present in the mouth ${ }^{3}$. It is generally considered that one can estimate age with accurate result from some month's in utero up to the age of twenty. This may be the case up to twelve years, but between that age and twenty years of age estimations are based only on the development of the root of the third molars.

Nolla $(1960)^{2}$ observed ten stages of development of teeth as follow as:

Stage (0) - Absence of crypt.

Stage (1) - Presence of crypt.

Stage (2) - Initial Calcification.

Stage (3) - 1/3 Crown Completed.

Stage (4) - 2/3 Crown Completed.
Keywords: Forensic odontology, Third molar, Age estimation, Eruption stages.

\section{*Correspondence to:}

Dr Anil Goyal,

Dept. of Pedodontics, Govt. Dental College, Jaipur, Rajasthan.

Article History:

Received: 15-06-2016, Revised: 08-07-2016, Accepted: 29-07-2016

\begin{tabular}{|l|c|}
\hline \multicolumn{2}{|c|}{ Access this article online } \\
\hline $\begin{array}{l}\text { Website: } \\
\text { www.ijmrp.com }\end{array}$ & Quick Response code \\
\hline DOI: & \\
10.21276/ijmrp.2016.2.4.040 & \\
\hline
\end{tabular}

Stage (5) - Crown almost completed

Stage (6) - Crown completed.

Stage (7) - 1/3 Root Completed.

Stage (8) - 2/3 Root Completed.

Stage (9) - Root almost completed apex open.

Stage (10) - Apical ends of roots completed.

According to Schour and massler (1941), ${ }^{4}$ the age of calcification of teeth are distinct process and may not correspond to those of chronological age. Lagan and kronfeld $(1954)^{5}$ observed that the crown of lower third molar completely develops between the age of 12 to 16 years, but further observed that the root of this tooth is completed at the age of 18 to 25 years. This study is an attempt to highlight the relation of the development of individual and eruption of third molar teeth in various age groups in both sexes by radiograph in Jaipur population.

\section{MATERIALS AND METHODS}

The randomized controlled trial study was conducted in the department of forensic medicine \& toxicology and radio-diagnosis department in S.M.S. hospital, Jaipur, Rajasthan. Total number of cases 200 (100 girls and 100 boys) both sexes, bearing age group between 13- 25 years. The candidate were chosen from different schools, colleges and outdoor in S.M.S. hospital, in Jaipur city. Only those cases were selected whose exact date of birth was verified by the school / college authority subjects residing for more than 10 years in Jaipur city were included in the study. 
The subjects for the study were divided into following groups: $13-$ 14 years, $14-15$ years, $15-16$ years, $16-17$ years, $17-18$ years, $18-$ 19 years, $19-20$ years, 20-21 years, 21-22 years, 22-23 years, 2324 years \& $24-25$ years. The subjects were examined clinically for recording physical parameters like height, weight, and general body development. Ages of onset of menarche along with development of breast were recorded in girls. Presence of hair in pubic, axillary, in both sexes and hair on face in cases of males were recorded. The dental examination of the subjects were done with the aid of mirror, probe and counting of teeth were recorded by palmer"s notation. The intra-oral periapical radiograph of upper and lower third molar teeth of all subjects were taken and observed regarding various stages by Nolla's stages of development of teeth.

\section{RESULTS AND OBSERVATIONS}

The present study shows different socioeconomic status (Upper class, Middle class \& Low class) in relation to different age groups (13-14 years to $24-25$ years) in boys \& girls (Table 1 ). Table 2 shows religion wise distribution of total number of cases. Table 3 show onset of menarche in respective age such as 12-13 years, $13-14$ years and $14-15$ years and $13.3 \%, 69.5 \%$ \& $17.1 \%$ respectively. Table 4 show the stages of eruption of third molar teeth in different age group.

Table 1: Showing different socioeconomic status in relation to different age groups in boys \& girls.

\begin{tabular}{|c|c|c|c|c|c|c|c|c|}
\hline \multirow{2}{*}{$\begin{array}{l}\text { Age groups } \\
\text { (in years) }\end{array}$} & \multirow[t]{2}{*}{ Total no. of girls } & \multirow[t]{2}{*}{ Total no of boys } & \multicolumn{2}{|c|}{ Upper Class } & \multicolumn{2}{|c|}{ Middle Class } & \multicolumn{2}{|c|}{ Lower Class } \\
\hline & & & Girls & Boys & Girls & Boys & Girls & Boys \\
\hline $13-14$ & 8 & 8 & 1 & 1 & 6 & 5 & 1 & 2 \\
\hline $14-15$ & 7 & 10 & 1 & 2 & 4 & 6 & 2 & 2 \\
\hline $15-16$ & 10 & 7 & 3 & 2 & 5 & 5 & 2 & 0 \\
\hline $16-17$ & 8 & 8 & 2 & 2 & 5 & 4 & 1 & 2 \\
\hline $17-18$ & 9 & 9 & 2 & 1 & 4 & 6 & 3 & 2 \\
\hline $18-19$ & 9 & 10 & 2 & 1 & 7 & 7 & 1 & 2 \\
\hline $19-20$ & 10 & 9 & 3 & 2 & 5 & 4 & 2 & 3 \\
\hline $20-21$ & 7 & 7 & 2 & 1 & 4 & 5 & 1 & 1 \\
\hline $21-22$ & 8 & 8 & 2 & 2 & 4 & 4 & 2 & 2 \\
\hline $22-23$ & 9 & 9 & 3 & 1 & 4 & 8 & 2 & 0 \\
\hline 23-24 & 7 & 7 & 1 & 0 & 5 & 6 & 1 & 1 \\
\hline $24-25$ & 8 & 8 & 2 & 1 & 5 & 4 & 1 & 3 \\
\hline
\end{tabular}

Table 2: Showing religion wise distribution of cases examined.

\begin{tabular}{lccccc}
\hline Age groups & Total no. of cases & \multicolumn{3}{c}{ Hindu } & \multicolumn{3}{c}{ Muslim } \\
\cline { 3 - 6 } (in years) & & Girls & Boys & Girls & Boys \\
$13-14$ & 16 & 7 & 8 & 1 & 0 \\
$14-15$ & 17 & 5 & 7 & 2 & 3 \\
$15-16$ & 17 & 8 & 5 & 2 & 2 \\
$16-17$ & 16 & 7 & 6 & 1 & 2 \\
$17-18$ & 18 & 6 & 5 & 3 & 4 \\
$18-19$ & 19 & 7 & 8 & 2 & 2 \\
$19-20$ & 19 & 6 & 6 & 4 & 3 \\
$\mathbf{2 0 - 2 1}$ & 14 & 4 & 5 & 3 & 2 \\
$\mathbf{2 1 - 2 2}$ & 16 & 6 & 5 & 2 & 3 \\
$\mathbf{2 2 - 2 3}$ & 18 & 7 & 6 & 2 & 3 \\
$\mathbf{2 3 - 2 4}$ & 14 & 4 & 7 & 3 & 0 \\
$\mathbf{2 4 - 2 5}$ & 16 & 6 & 5 & 2 & 3 \\
\hline
\end{tabular}

Table 3: Showing onset of menarche in respective age.

\begin{tabular}{lcc}
\hline No .of Girls & Age of onset of menarche & Percentage (\%) \\
\hline 14 & $12-13$ Years & $14.00 \%$ \\
68 & $13-14$ Years & $68.00 \%$ \\
18 & $14-15$ Years & $18.00 \%$ \\
\hline
\end{tabular}


Table 4: Showing eruption of third molar teeth in different age groups.

\begin{tabular}{lcccccc}
\hline Age group & \multicolumn{2}{c}{ No. of cases } & \multicolumn{3}{c}{ Developmental stage of teeth } \\
\cline { 2 - 7 } (in years) & Girls & Boys & Maxillary & \multicolumn{3}{c}{ Mandibular } \\
$13-14$ & 8 & 8 & - & - & - & - \\
$14-15$ & 7 & 10 & - & - & - & - \\
$15-16$ & 10 & 7 & 3 & 3 & 3 & 3 \\
$16-17$ & 8 & 8 & 7 & 7 & 7 & 7 \\
$17-18$ & 9 & 9 & 8 & 8 & 8 & 8 \\
$18-19$ & 9 & 10 & 8 & 8 & 8 & 8 \\
$19-20$ & 10 & 9 & 9 & 9 & 9 & 9 \\
$20-21$ & 7 & 7 & 9 & 9 & 9 & 9 \\
$21-22$ & 8 & 8 & 10 & 10 & 10 & 10 \\
$22-23$ & 9 & 9 & 10 & 10 & 10 & 10 \\
$23-24$ & 7 & 7 & 10 & 10 & 10 & 10 \\
$24-25$ & 8 & 8 & 10 & 10 & 10 & 10 \\
\hline
\end{tabular}

\section{DISCUSSION}

The present study included 200 cases, indicates that Socioeconomic status have no effect on the eruption and development of various stages of third molar teeth. The findings are not consistent with Rose $(1909)^{6}$ who commented that the teeth in well to do families erupt earlier as compared to those from poor families. The findings are also inconsistent with Brauer et al $(1942)^{7}$ who observed nutrition play a part in the calcification and eruption of the teeth. The possible reason for this contradiction is that above cited authors have studied the teeth of children.

Table 2 show the distribution of cases according to religion \& observation of present study show that the religion of an individual does not show any difference in the eruption and development of third molar teeth. Breast development commences prior to the age of 13 years but in present study earlier stages of development of breast could not be observed because the limit of age in this study is 13 years to 25 years of age groups. Pubic hair appeared at the age of 13-14 years in both sexes and axillary hair at the 13-14 years in girls and 14-15 years in boys in majority of cases. Observations are similar to those observed in Modi ${ }^{8}$, Parikh $^{9}$ and Nandi10. In the age group of 13-14 years crown completion of the third molar was found in most of the cases and at the age of 14-15 years crown completion stage was observed in $100 \%$ cases in both sexes. Demirijaner et al (1985) ${ }^{11}$ who given the opinion that dental development are independent of somatic and or sexual maturity. The present study showed that the age of menarche in majority of cases is 13-14 years. The crown of third molar teeth was seen completed in most of the cases at these age groups. The observation of present study shows that the eruption of third molar is seen in age group of 17-18 years. The findings of eruptions of third molar are consistent with Modi ${ }^{8}$ (1991) but not consistent with observation of Powell ${ }^{12}$ (1953), who while working as police surgeon of Bombay give the upper limit 14 years for third molar teeth in Indian children. As soon as second molar teeth erupts the space for the third molar teeth start to form and it was seen well marked at the age 16-17 years in most of cases in present study.

Third molar teeth in mandible have reflected earlier eruption in comparison to maxilla. The tipoff crown of third molar tooth was seen in most of the cases and the finding are consistent with
Schranz ${ }^{13}$ (1959) but not consistent with Koski14 et al (1957) who concluded that molars do not cut the gums until they have almost reached the occlusal level. The findings are also similar to Adler (1959) who observed that eruption is not bilaterally symmetrical. These finding are not inconsistent with observations of Schranz ${ }^{13}$ (1959). The $2 / 3$ rd of root completion stage of third molar teeth was seen in most of case and usually erupts at this stage. These finding are consistent with Orban (1928) that eruptions of the teeth is intimately related to elongation of the roots of teeth but not consistent with Carison ${ }^{15}$ (1944) who observed that elongation of the root and movement of the crown towards the oral cavity do not necessarily occur together.

\section{CONCLUSION}

Socio-economic status, racial and physical characters have no effect on the eruption and development of various stages of third molar teeth. No significant difference was observed in the development stage of third molar teeth in girls and boys. Third molar teeth eruption alone should not be used for age estimation. Agenesis of third molar is more in case of girls than in boys.

\section{REFERENCES}

1. Shamim T, Ipe Varghese $V$ et al. Age Estimation: A Dental Approach: JPAFMAT 2006; 6. ISSN 0972-5687.

2. Reddy K.S.N. Identification; The synopsis of Forensic Medicine and Toxicology; (ed.) 8th, 1992; 28-45.

3. Rajdan D. A study of third molar teeth in Indian subjects of Uttar Pradesh; J. Ind. Dent. Assoc 1996; 67(1); page 7.

4. Schour I and Massler M. The development of the human dentition; J. Am. Dent. Assoc 1941. 28, Page: 1153.

5. Lagan, W.H.G. and kronfield, R. Estimation of age. In basic reading on identification of human skeletons. Ed. By T. D. Stewart and M. Trotter. Newyork: Wenner Green foundation for othopological research 1954, Ine. 10th Edition.

6. Rose $C$. UberdieMittlereDurchbruchrzeit der beibenderZahne der menschen: Cited from Forensic Odontology by Gustafson 1909.

7. Brauer J.C. and Bahadur M.A. Variation in calcification and eruption of the deciduous and permanent teeth. J. Am. Dent. Assoc 1942; 24; 1373. 
8. Modi. Personal identity, Modi,s Medical Jurisprudence and Toxicology; Butterworth,s (edi.) 22nd, 1988; 35 - 42.

9. Parikh. Personal identity, Parikh's Textbook of Medical Jurisprudence and Toxicology. C.B.S. (edi.) 5th; 1990, 39 - 50.

10. Apurba Nandy: Textbook of "Principles of Forensic Medicine including Toxicology" New Central Book Agency (p) Ltd.

11. Demirijaner A, Buschang P.H, Tanquary R, Patterson D.K. Interrelationships among measures of somatic, Skeletal, Dental and sexual maturity. Am. J. Orthod 1985: Nov. 88(5); page no. 433.

12. Powell A. Lyon"s Medical Jurisprudence for India, Gravel 10th edition 1953.

13. Schranz, D. Kritik der Auswertung der Alters bestinnungsmerk mal vesszahner und Knochen; Cited from Forensic Odontology by Gustafson 1959.

14. Koski K. and Garn S.M. Tooth eruption sequence in fossil and modern man, Amer. J. Anthrop 1957; 15: 469.
15. Carison. Studies on the rate and amount of eruption of certain human teeth. Am. J. Orthodont 1944, 30, page 578.

\section{Source of Support: Nil. Conflict of Interest: None Declared.}

Copyright: () the author(s) and publisher. IJMRP is an official publication of Ibn Sina Academy of Medieval Medicine \& Sciences, registered in 2001 under Indian Trusts Act, 1882.

This is an open access article distributed under the terms of the Creative Commons Attribution Non-commercial License, which permits unrestricted non-commercial use, distribution, and reproduction in any medium, provided the original work is properly cited.

Cite this article as: Anil Goyal. The Relation of Eruption of Third Molar Teeth and the Development of Individual in Jaipur Population. Int J Med Res Prof. 2016; 2(4):166-69. 